\title{
エネルギー消費起因の二酸化炭素排出量推計モデルの開発と わが国の二酸化炭素排出量の見通しについて
}

\author{
Projections of Carbon Dioxide Emission from Energy Consumption in Japan
}

松岡 譲 ${ }^{1}$, 森田 恒幸 ${ }^{2}$, 日比野 剛 ${ }^{3}$, 水野 健太 ${ }^{4}$

Yuzuru MATSUOKA, Tsuneyuki MORITA, Goh HIBINO, and Kenta MIZUNO

\begin{abstract}
In this paper, we introduce our enduse-type carbon dioxide emission model and project carbon dioxide emission in Japan by using it. The model calculates a combination of energy devices to be used so as to minimize the total cost for supplying energy services. And, the model counts carbon dioxide emissions from the direct consumption of energy by the selected energy devices. Based on the projections, we report carbon dioxide emission on 2010 will be $357 \mathrm{MtC}$ (technology share fixed case) and $341 \mathrm{MtC}$ (technology selection case), compared with $320 \mathrm{MtC}$ on 1990.
\end{abstract}

Keywords; Carbon dioxide emission, Energy end-use model, Linear Programming

\section{1 はじめに}

本論文では, 著者らが開発しているエネルギー消費起因の二酸化炭素排出量を最終消費側から推計するモテルの大 略と，それを使用して推計したわが国の二酸化炭素排出量の見通しについて報告する。

本研究で開発したモテルは，エネルギー技術型のエンドユーズモテルに属すものである。このモテルでは，エネル ギー消費者が需要するエネルギーサービスを，あらかじめ与えておいた技術種を組み合わせることによって充足させ る。技術選択の基準としては，資源制約などの条件下にて機器購入及び維持管理費用の現在評価額がもっとも少ない 組み合わせとし，エネルギーサービスあるいは制約条件については，外生的あるいは技術ストックの履歴によって定 める。エネルギー機器あるいは技術は，導入年別にコーホート（ビンテージ）に分けられ，各コーホートには余命の 他, 固有の技術・経済特性が付与されている。さらに, 本モテルでは, 二酸化炭素排出に係わる賦課金（炭素税）あ るいは特定の技術への補助金などの効果を，上記の技術選択メカニズムに基づいて組み込むアルゴリズムを有してい る。このモテルは，原則的には一国あるいは一地域のエネルギー消費全部門にまたがって適用することを想定してい るが, 民生，産業などの部門間の関連性を捨象してよい場合には，部門単独のシミュレーションも可能である。本モ テルの入力情報には，現在及び計算期間における各エネルギー技術毎の詳細な技術テータ，経済性テータ及び計算開 始年におけるコーホート量が必要となる。これらの詳細な情報を用いることによって，それらが意味する技術・経済 特性の二酸化炭素排出に及ぼす影響度を評価することができる。この点は本モデルの大きな長所である。

現在，著者らは本モテルを用い，わが国，韓国，中国，インド及びインドネシアにおける $2010 〜 2020$ 年頃までの二 酸化炭素排出量の推計作業を行っている。それらのうち，本論文で報告するものは，わが国における 1990年〜2010 年の二酸化炭素排出量の見通しを行った部分であり，その主要な結果は以下の通りであった。

1) エネルギー技術のサービス分担率を 1995 年時点にて固定した推計では, 1990 年時点の排出総量 $320 \mathrm{MtC} / \mathrm{a}$ は, 2000 年には $332 \mathrm{MtC} / \mathrm{a}$ に，また 2010 年には 1990 年の約 $10 \%$ 増である $357 \mathrm{MtC} / \mathrm{a}$ となった。

2) エネルギー技術選択を行った場合の推計では，電気炬，直噴エンジン搭載車などの省エネ技術の普及が見込ま れ，2000年には $330 \mathrm{MtC} / \mathrm{a} ， 2010$ 年には 1990 年の約 $6 \%$ 増である $341 \mathrm{MtC} / \mathrm{a}$ となった。

3) 炭素税を賦課した場合, 2010 年排出量を 1990 年排出量までに抑制するには炭素トンあたり 1 万円程度の課税が 必要であった。

\footnotetext{
1名古屋大学工学部地圈羁境工学教室

2 国立㻴境研究所地球環境研究グループ

3富士総合研究所

4名古屋大学大学院工学研究科土木工学専攻
} 
4) 炭素税賦課に加え，それを還元することにより二酸化炭素排出量を少なくする技術選択の誘導を目的とした補 助金交付を行うと，炭素トンあたり 3 千円程度の課税で 2010 年排出量を 1990 年排出量以下に抑制することが 可能であった。

\section{2 本研究で採用したエネルギー技術モデルの系譜とその特徵}

本研究で採用したモデは，ボトムアップ型のエネルギー技術モテルに属している。今までにエネルギー消費起源 の温室効果ガス排出モテルは数多く開発されているが，大きく 2 つのタプに分類することができる。第一は, 経済 学的なモテルを出発点とするものであり, 価格と弾性值を主たる経済的指数として, それらとエネルギーの消費や生 産との関係を集約的に表現するもので，トップダウン型モテルと呼ばれる。第二は，エネルギーの消費や生産をつか さどる人々の活動やそこで使われる技術の変化に焦点を置き，これらの詳細な記述から全体としてのエネルギーの消 費や生産を積み上げ方式で予測していくモテルで，ボトムアップ型モテルと呼ばれる。ボトムアップ型モテルの最大 の長所は, 人間活動や技術の変化の詳細な記述を基礎に予測するため, 予測結果を具体性を持って解釈できることに ある。新たな政策を導入する際に，政策の具体的展開の方向とその効果を政策決定者に対して説明するには，具体性 と説得性を持ったこの種のボトムアップ型モテルが不可欠となる。

今まで，ボトムアップ型モテルは二つの方向で開発されてきた。一つは，エネルギーの供給・転換の側面に焦点を 当て, より効率の高い技術やその組み合わせを分析するためのモテルで, 国際エネルギー機関が中心となって開発し たMARKAL (Fishbone and Abilock, 1981) やフランスで開発されたEFOM（Finon，1974）などがこの分野の代 表的なモテルである。もう一つは，エネルギーの需要・消費の側面に焦点を当てて，各セクタ一毎に人間活動の変化 がエネルギー需要をどう変化させるかについて詳細な積み上げ計算を行うモテルで, 通常「エンドユーズ・モデ」 と呼ばれている。この種のモテルとしては, フランスのMEDEE (Chateau and Lapillonne, 1979) やストックホル ム環境研究所が開発したLEAP（SEI-B，1993）が有名である。しかし，エネルギー需要・消費の側面に焦点を当て てより効率の高い技術やその組み合わせを分析する「エンドユーズ・エネルギー技術モテル」については, 開発が進 展しているとは言い難かった。

わが国の二酸化炭素排出量を減らすには，このエンドユーズの側面で，どのような省エネ技術がどこまで導入でき るかが大きな鍵を握っており，この意味からエンドユーズ・エネルギー技術モテルの開発が必要となってきている。 本モテルでは，エネルギー価格の変化により技術代替が生じる現象を中心にして，エネルギー消費の変化を積み上げ 方式により推定できる。したがって，個々の具体的な政策の有効性を評価したり，種々の政策を組み合わせた場合の 効果を算定することが可能である。また，エネルギー需要モテルに技術選択モテルをつなぐことによって，個々の技 術の実態を踏まえたエネルギー効率の改善を予測可能にしている。

しかし，その一方で, 本モテルには幾つかの限界がある。第一に, エネルギーサービス需要をシナリオによって与 えているため, エネルギー価格上昇の直接的な需要抑制効果や消費の抑制, 眝蓄の減少を通じた間接的な経済影響を 考慮しておらず，マクロ経済的なロスを推定するには不向きである。第二に，技術選択の際に制度面の障害等の社会 的なコストを考虑していないので，個々の技術選択による二酸化炭素排出削減が大きめに見積もられる可能性がある。 第三に，実用可能性が低いと考えられている技術を対象としていないなど，対象とした技術が包括的でないため，全 体として二酸化炭素排出の削減量が小さめに見積もられる可能性がある。これらの限界は，エネルギー技術モテルの 本質的制約に基づくものもあり，また，本モテルが開発途上にあることに起因するものもある。したがって，本研究 結果を解釈する際にもこれらの点に注意する必要がある。しかし，これらを勘案してもなお個々の具体的な政策の有 効性を評価したり, 種々の政策を組み合わせた場合の効果を評価するツールとして, 本モテルはその具体性と政策支 援能力において，大変優れているものとして考えている。

\section{3 モデルの概要}

\section{1 技術の選択基準}

本モデルが対象とするシステムでは，システム外部から投入されたエネルギーをもとに，これをサービスへと転換 するエネルギー消費機器群が作動する。機器群は外生的に定められた以上のサービス需要量を満足すべくシステムに 導入される。その際, 機器群はシステムへの参入時期によってコーホートに分けられ, 耐用期間が終わったものは退 
役する。技術選択は, 時間に沿って区分された期毎に行われ, 各期の機器ストック量, 改良量, 退役量および新規参 入量などを考虑しその期のサービス需要量を満たすことが出来るように調整が行われる。本モデルではエネルギー技 術，技術改良などに関し以下の前提を設けている。

1) 各エネルギー技術は，1 種以上のエネルギーを消費し，1種以上のサービスを産出する。その量はその技術を 実現している機器の産出サービス量によって計測する。

2) 各技術に，改良の付加程度により，1，2，3，...なる改良段階を表す数値を割り振り，この数値を以下技術 段階と称する。ある期に参入あるいは改善される同一種の技術は同一技術段階に属す。技術段階を表す数値は, 導入年が新しいものほど大きくなる。

3）技術導入年および段階別にサービス効率，エネルギー効率，初期固定費用が定まっている。技術種および導入 期別の機器の 1 群をコーホートと称する。各コーホートには, 属性としてサービス量供給能力, エネルギー消 費特性，余命が付随している。

4) サービス需要量の変化および機器の退役, 技術改良は, コーホートの入れ替えを発生させる。その際, 以下の三 種類のコーホート変化が問題となる。その第一は機器の余命が 0 になったことによる退役および需要サービス 増大に伴う新規機器の導入である。第二は, 既参入の機器の改良に伴う変化である。第三はコーホートの余命 が残っているのにも拘わらず，新規機器によって既参入のコーホートが代替される場合である。新規機器の導 入にあたっては, 後述の式 (2) 及び式 (3) に示す費用を計上する。既参入機器の改良には, 改良前の段階と改良 後の段階の固定費用差及び改良後の維持管理費用を年価に換算したものを計上する。第三の場合の費用計上は, 第一の場合と同じである。すなわち，代替される既参入コーホートの未償却価値は考慮せず埋没費用とみなす。

本モテルでは, エネルギー消費技術を中心に, 現行の機器保有状況等を考慮しながら, エネルギー使用によって発 生する諸費用を計算し，もっとも安価なオプションを採用した場合の二酸化炭素排出量を算定する。比較の対象とな る諸費用とは，エネルギー機器に関する固定費用，エネルギー費用など維持管理に係わる費用および排出賦課金など のガス排出に係わる費用を合算したものであり，年価で表現する。本モテルの目的関数を以下の式で表す。

$$
\sum_{i=1}^{N} c_{i} \cdot x_{i} \cdot\left(1-\beta_{i}\right) \rightarrow \text { minimum }
$$

ここに， $c_{i}$ は上記の項目に関する諸費用をコーホート一単位あたりで示したものである。 $x_{i}$ は第 2 種のコーホート 量, $N$ はコーホート数, $\beta_{i}$ は補助金率である。諸費用 $c_{i}$ は二種類の方法で算出する。第一は, 購入から償却までの費用 を, 時間的割引を考え年価に換算したALC (Annualized Life-cycle Cost)で評価する方法である。第二は, オプショ ン間の初期投資費用増を維持管理費用減で回収する期間長によって評価する回収期間長法 (Pay-back Time Method, PTM）である。後者の場合, 資本利率による調整は行っていない。また, エネルギーと関連財との間に代替関係が ある場合, 関連財の購入・加工費用が問題となる。本モデルでは, それらの関連財とエネルギーのフローを区別せず, また，その加工機器（技術）とエネルギー消費機器（技術）を区別しない。両者を合わせ，エネルギーおよびエネル ギー消費技術で総称し取り扱っている。

$\mathrm{ALC}$ 法による諸費用 $c_{i(A L C)}$ は，各コーホートについて以下の式で算出する。

$$
c_{i(A L C)}=P_{i} \cdot \frac{\theta(1+\theta)^{L_{i}}}{(1+\theta)^{L_{i}}-1}+\sum_{k=1}^{M} E_{k} \cdot\left(p_{k}+\zeta_{k}\right)
$$

ここに, $P_{i}$ は機器導入時の現価, $\theta$ は利子率, $L_{i}$ はコーホート $i$ の余命, $E_{k}$ は第 $k$ 種のエネルギー消費量, $p_{k}$ は第 $k$ 種 のエネルギー価格， $M$ は使用エネルギー種の数， $\zeta_{k}$ は第 $k$ 種のエネルギーに課される単位エネルギーあたりの炭素税 を表す。一方, 回収期間長法 (PTM) に基づく評価の場合は, 各機器について以下の式で算出する。

$$
c_{i(P T M)}=\frac{P_{i}}{\min \left(T, L_{i}\right)}+\sum_{k=1}^{M} E_{k} \cdot\left(p_{k}+\zeta_{k}\right)
$$

ここにTは基準回収年長である。 


\section{2 補助金交付について}

機器毎に定められる補助金率 $\left(\beta_{i}\right)$ は前期までの炭素税収入を原資とし, 補助金交付者（政府）亡機器選択者の 2 者間のシュタッケルベルグ的行動（Varian，1984）を仮定して定めている。すなわち, 両者は以下のような前提で行 動するものと考え, 政府 (上位レベル) と機器選択者（下位レベル）の線形 2 レベル最適化モテル（志水, 1982）と してモデル化した。

1) 機器選択者は, 政府によってあらかじめ定められている補助金率を考慮しながら, エネルギーサービスに必要 となる純コスト (年価評価) が最小となる機器選択を行う。

2) 一方, 政府は, 各期毎にエネルギー機器選択者の挙動を考慮しながら, 各機器の補助金率を二酸化炭素排出量 が最小となるように決定する。その際の補助金総額はあらかじめ定めている限度額を超えず，その原資は前期 までの炭素税収入とする。

本モデルで考える税収還元方法は，現実の政策と照らし合わせたとき以下のような問題がある。

1) 污染者負担の原則に適合しない場合がある。

2) システム全体としては二酸化炭素排出量は抑制されるが, 補助金による初期投資費用の低下によって污染者の 市場参入を促進させる可能性がある。

3) 政府部門が污染者に対する対策コストに関する詳細な情報を入手し, 合理的な決定・指導を行いうる「賢い政 府」の行政指導体制が必要不可欠な要件となる。

このような問題点を考慮するならば，炭素税と補助金の組み合わせによる排出量削減方策は，長期的な抑制政策とは なりえず，炭素税導入初期における適応的政策として位置づけることが適当と考えられる。

\section{4 わが国の二酸化炭素排出量の推計}

\section{1 設定シナリオについて}

本モテルの適用例として，わが国における二酸化炭素排出量の将来見通しを行った。計算は 1990 年を基準年とし， 当年におけるコーホートの調整及び二酸化炭素排出量計算値のキャリブレーションを行い, 2010 年までの排出量を 1 年刻みで推計した。キャリブレーションに使用した対照データは, 環境庁により取りまとめられたもの（環境庁地球 環境部，1994）を使用した。また，炭素税を導入する場合の開始年は1997年とし，費用の年価評価は回収期間長法を 採用し，基準回収年長 $T$ は 3 年とした。補助金の限度額は, 前年における炭素税収入と前年において繰り越された補 助金残高を足し合わせたものであり，部門毎に独立して税徵収と還元を行うものと仮定した。

シミュレーションは, 家庭, 業務, 運輸, 産業各部門について行った。エネルギー転換部門からの排出分は前 4 部門 に帰属させ算出している。産業部門は, 鉄鋼, 紙・パルプ, セメント, 石油化学, その他産業に分類し, はじめの 4 分 野について本モデルを用いた推計を行った。その他産業は通産省産業政策局（1994）の報告による将来の産業生産額 に比例した排出量の仮定を行った。また，本モデルで最終サービス需要を算定する根拠となる経済成長率については, 1995 年 12 月にわが国政府が策定した新経済計画に基づき，1994 年から 2000 年までを年率 $3.0 \%$ とた。また, 2000 年以降は $2.0 \%$ と仮定した。エネルギ一価格や業務部門における照明サービス, 家庭部門における冷暖房サービスなど のサービス需要量変化については適宜，諸資料，ヒアリング等に基づき設定した（AIM/Japan 開発チーム，1994）。 既設の汽力発電施設を改造して出力増加や効率向上を図るリパワリングや燃焼に伴うエネルギーの多段階利用を行う 複合化サイクル発電の普及および購入電力の二酸化炭素排出原単位変化などの見通しは電気事業審議会需給部会中間 報告（資源エネルギー庁，1996）に基づき算定した。モテルに取り上げた技術種を表 1 に一覧する。

想定したシナリオは，技術の普及状況が 1995 年以降変わらないとするサービス分担率固定ケース, 式(1)に基づい た機器選択行動を行わせる技術選択ケース (エネルギー転換部門における既設発電施設のリパワリング, 複合化サイ クル発電対策の有無による 2 ケース), 炭素税賦課ケース (炭素トンあたり 3 千円, 1 万円, 3 万円), 炭素税収還 元ケース（炭素税 3 千円）の 7 ケースである。 
表 1 本モデルで取り上げたエネルギー技術

\begin{tabular}{|c|c|c|}
\hline 部門 & 分野 & エネルギー技術 \\
\hline \multirow{4}{*}{ 産業 } & 鉄鋼 & 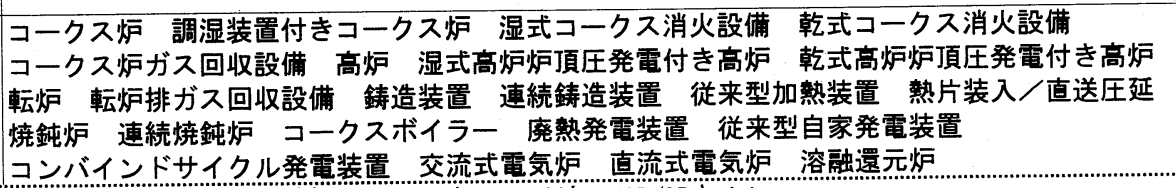 \\
\hline & セメント & 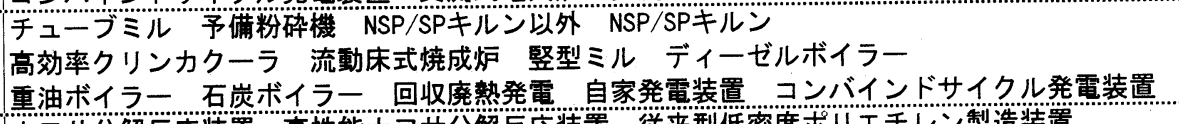 \\
\hline & 石油化学 & 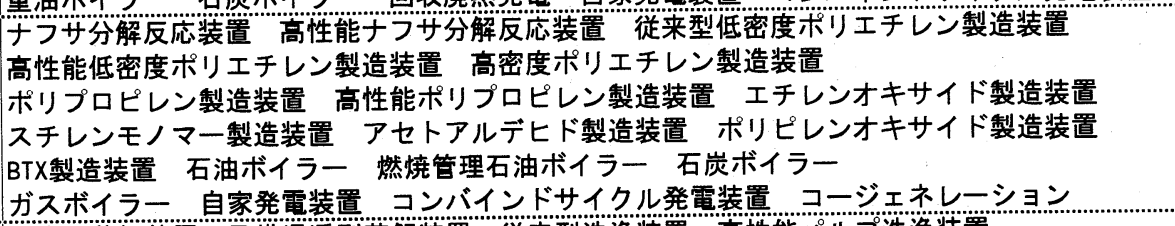 \\
\hline & 紙パルブ & 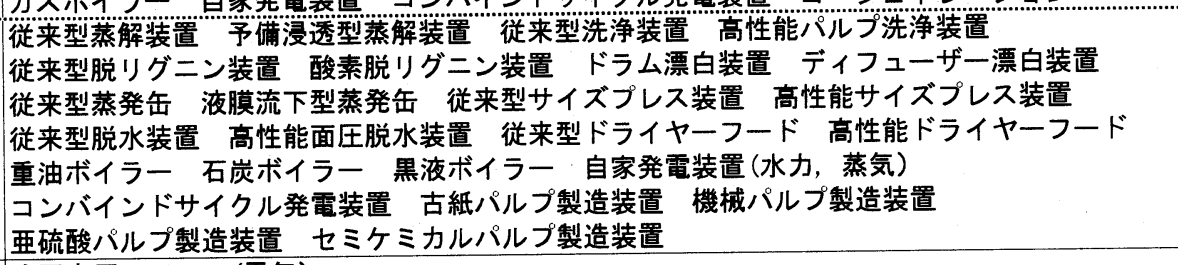 \\
\hline \multirow{7}{*}{ 家庭 } & 冷房 & 冷房専用エアコン(雷気) \\
\hline & 冷暖房 & 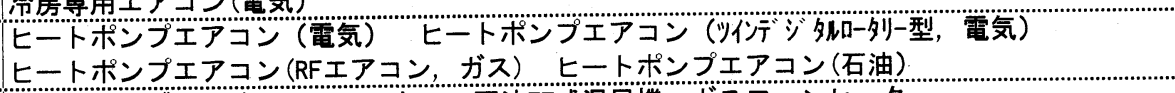 \\
\hline & 暖房 & 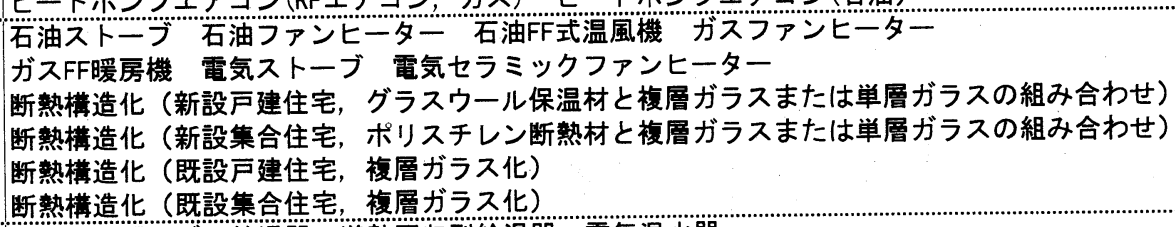 \\
\hline & 給湯 & 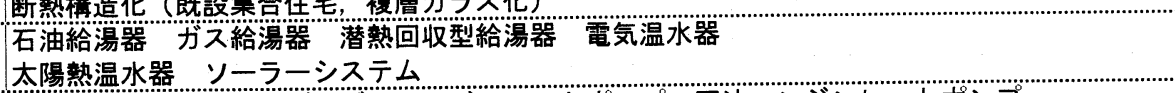 \\
\hline & 泠暖房 - 給湯 & 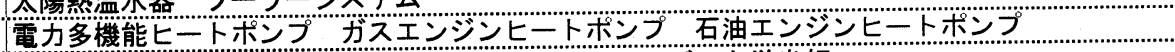 \\
\hline & 照明 & 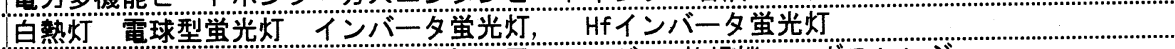 \\
\hline & 動力その他 & テレビ 泠涷泠蔵庫 洗䍜機 嫦除機 電子レンシ，乾燥機，ガスレンジ \\
\hline \multirow{10}{*}{ 業務 } & 冷房 & 冷房専用エアコン(霊気) \\
\hline & 泠暖虏 & 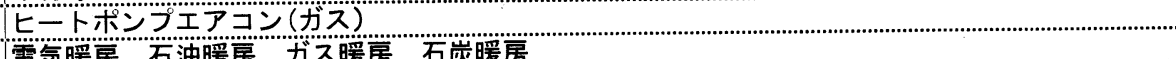 \\
\hline & 暖房 & 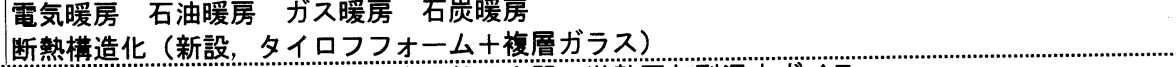 \\
\hline & 給湯 & 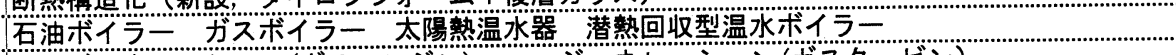 \\
\hline & $\begin{array}{l}\text { 電力·泠房 } \\
\text { 暖房....給湯 }\end{array}$ & 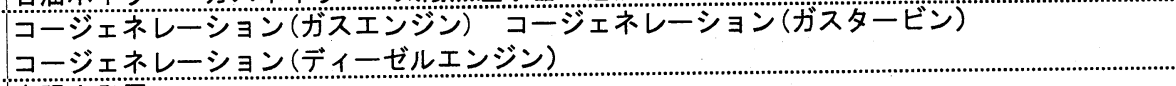 \\
\hline & 轌力 & 太䧁光発電 \\
\hline & 一般照明 & 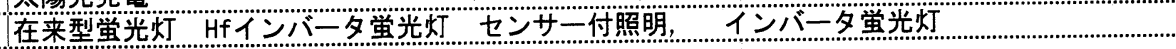 \\
\hline & 非常口照盟 & 通常誘導灯 高輝度誘導灯 \\
\hline & 霯放 & 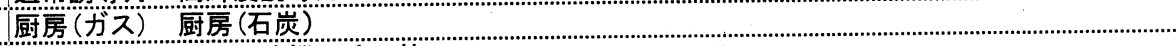 \\
\hline & 動力その他 & 計算機 複写機 并降機 その他" \\
\hline \multirow[b]{2}{*}{ 運輸 } & 旅客輸送 & 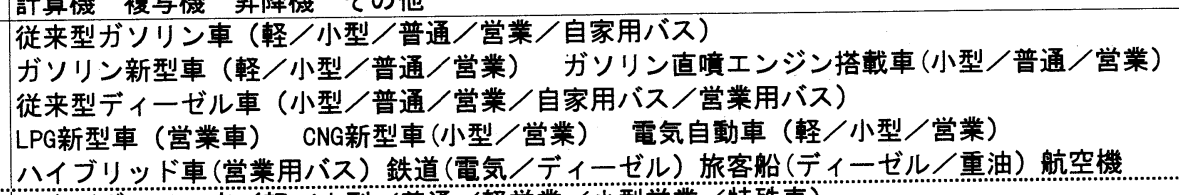 \\
\hline & 貨物輸送 & 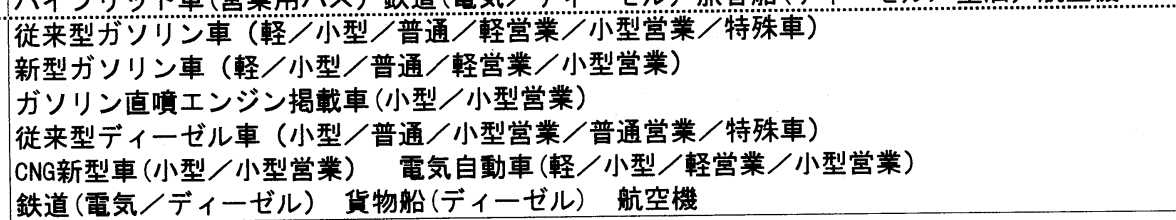 \\
\hline
\end{tabular}




\section{2 推計結果について}

表 2 は, 本シミュレーションの結果を部門別にまとめたものである。表中の上段は排出量 $(\mathrm{MtC} / \mathrm{a})$ を表し, 下段 は，1990年排出量と比較したときの排出量の伸びを表す。図 1 は, 2000 年及び 2010 年における排出総量を各シナリ オ別に示したものである。

表 2 シミュレーション結果一覧

\begin{tabular}{|c|c|c|c|c|c|c|c|c|}
\hline \multirow[b]{2}{*}{ 部門 } & \multirow[b]{2}{*}{ 年 } & \multirow{2}{*}{\begin{tabular}{|c|} 
サービス分担率 \\
固定ヶース
\end{tabular}} & \multirow{2}{*}{$\begin{array}{c}\text { 技術選択 } \\
\text { ケース }\end{array}$} & \multirow{2}{*}{$\begin{array}{c}\text { 技術選択 } \\
\text { ケース }\end{array}$} & \multicolumn{3}{|c|}{ 炭素税賦課ケース } & \multirow{2}{*}{$\begin{array}{c}\text { 税収還元ケース } \\
(¥ 3,000 / \mathrm{tC})\end{array}$} \\
\hline & & & & & $¥ 3,000 / \mathrm{tC}$ & $¥ 10,000 / \mathrm{tC}$ & $¥ 30,000 / \mathrm{tC}$ & \\
\hline \multirow{3}{*}{ 産業 } & 1990 & 153.8 & 153.8 & 153.8 & 153.8 & 153.8 & 153.8 & 153.8 \\
\hline & $2000^{\circ}$ & $\begin{array}{r}150.0 \\
-2.5 \%\end{array}$ & $\begin{array}{r}146.8 \\
-4.8 \%\end{array}$ & $\begin{array}{r}149.5 \\
-2.9 \% \\
\ldots .9 \%\end{array}$ & $\begin{array}{r}147.6 \\
-4.2 \%\end{array}$ & $\begin{array}{r}146.5 \\
-5.0 \%\end{array}$ & $\begin{array}{r}145.3 \\
-5.8 \%\end{array}$ & $\begin{array}{r}145.8 \\
-5.2 \%\end{array}$ \\
\hline & 2010 & $\begin{array}{r}156.6 \\
1.8 \% \\
\end{array}$ & $\begin{array}{c}151.8 \\
-1.3 \% \\
\end{array}$ & $\begin{array}{r}144.7 \\
-6.3 \% \\
\end{array}$ & $\begin{array}{r}144.6 \\
-6.4 \% \\
\end{array}$ & $\begin{array}{c}143.8 \\
-7.0 \%\end{array}$ & $\begin{array}{c}142.4 \\
-8.0 \%\end{array}$ & $\begin{array}{c}134.8 \\
-12.4 \%\end{array}$ \\
\hline \multirow{3}{*}{ 家庭 } & 1990 & 38.0 & 38.0 & 38.0 & 38.0 & 38.0 & 38.0 & 38.0 \\
\hline & $2000^{\circ}$ & $\begin{array}{c}46.4 \\
18.1 \%\end{array}$ & $\begin{array}{r}44.7 \\
15.0 \%\end{array}$ & $\begin{array}{l}43.2 \\
12.0 \%\end{array}$ & $\begin{array}{c}43.2 \\
12.1 \%\end{array}$ & $\begin{array}{l}43.2 \\
12.1 \%\end{array}$ & $\begin{array}{c}41.1 \\
7.6 \%\end{array}$ & $\begin{array}{l}42.9 \\
11.4 \%\end{array}$ \\
\hline & $2010^{\circ}$ & $\begin{array}{c}57.4 \\
33.8 \% \\
\end{array}$ & $\begin{array}{r}51.0 \\
25.5 \% \\
\end{array}$ & $\begin{array}{r}44.9 \\
15.4 \% \\
\end{array}$ & $\begin{array}{l}44.0 \\
13.7 \% \\
\end{array}$ & $\begin{array}{r}42.6 \\
10.8 \% \\
\end{array}$ & $\begin{array}{c}42.4 \\
10.4 \% \\
\end{array}$ & $\begin{array}{l}43.5 \\
12.7 \% \\
\end{array}$ \\
\hline \multirow{3}{*}{ 業務 } & 1990 & 33.6 & 33.6 & 33.6 & 33.6 & 33.6 & 33.6 & 33.6 \\
\hline & 2000 & $\begin{array}{c}37.6 \\
10.6 \%\end{array}$ & $\begin{array}{c}37.5 \\
10.4 \%\end{array}$ & $\begin{array}{c}36.3 \\
7.4 \% \\
\ldots .7\end{array}$ & $\begin{array}{c}36.3 \\
7.4 \% \\
\end{array}$ & $\begin{array}{c}36.3 \\
7.4 \%\end{array}$ & $\begin{array}{c}36.3 \\
7.4 \%\end{array}$ & $\begin{array}{c}36.2 \\
7.3 \%\end{array}$ \\
\hline & 2010 & $\begin{array}{r}42.6 \\
21.1 \% \\
\end{array}$ & $\begin{array}{r}38.8 \\
13.4 \% \\
\end{array}$ & $\begin{array}{l}35.1 \\
4.3 \% \\
\end{array}$ & $\begin{array}{l}35.1 \\
4.3 \% \\
\end{array}$ & $\begin{array}{l}35.1 \\
4.3 \% \\
\end{array}$ & $\begin{array}{l}35.1 \\
4.3 \% \\
\end{array}$ & $\begin{array}{l}34.9 \\
3.7 \% \\
\end{array}$ \\
\hline \multirow{3}{*}{ 運輸 } & 1990 & 58.5 & 58.5 & 58.5 & 58.5 & 58.5 & 58.5 & 58.5 \\
\hline & $2000^{\circ}$ & $\begin{array}{c}62.1 \\
5.8 \%\end{array}$ & $\begin{array}{c}61.7 \\
5.2 \%\end{array}$ & $\begin{array}{c}61.5 \\
4.9 \%\end{array}$ & $\begin{array}{c}61.5 \\
4.9 \%\end{array}$ & $\begin{array}{c}60.3 \\
3.0 \%\end{array}$ & $\begin{array}{r}60.2 \\
2.8 \%\end{array}$ & $\begin{array}{c}60.9 \\
3.9 \%\end{array}$ \\
\hline & 2010 & $\begin{array}{c}64.2 \\
8.9 \% \\
\end{array}$ & $\begin{array}{c}63.3 \\
7.6 \% \\
\end{array}$ & $\begin{array}{r}62.8 \\
6.8 \% \\
\end{array}$ & $\begin{array}{c}62.4 \\
6.3 \% \\
\end{array}$ & $\begin{array}{r}61.9 \\
5.5 \% \\
\end{array}$ & $\begin{array}{r}61.9 \\
5.5 \% \\
\end{array}$ & $\begin{array}{r}61.1 \\
4.3 \% \\
\end{array}$ \\
\hline \multirow{3}{*}{ 合計 } & 1990 & 320.0 & 320.0 & 320.0 & 320.0 & 320.0 & 320.0 & 320.0 \\
\hline & 2000 & $\begin{array}{r}332.2 \\
3.7 \%\end{array}$ & $\begin{array}{r}329.5 \\
2.9 \%\end{array}$ & $\begin{array}{r}324.7 \\
1.4 \%\end{array}$ & $\begin{array}{r}324.7 \\
1.4 \%\end{array}$ & $\begin{array}{r}322.4 \\
0.7 \%\end{array}$ & $\begin{array}{l}319.0 \\
-0.3 \%\end{array}$ & $\begin{array}{r}321.9 \\
0.6 \%\end{array}$ \\
\hline & 2010 & $\begin{array}{r}356.9 \\
10.3 \% \\
\end{array}$ & $\begin{array}{r}341.0 \\
6.2 \% \\
\end{array}$ & $\begin{array}{r}323.5 \\
1.1 \% \\
\end{array}$ & $\begin{array}{r}322.3 \\
0.7 \% \\
\end{array}$ & $\begin{array}{r}319.5 \\
-0.2 \% \\
\end{array}$ & $\begin{array}{r}317.8 \\
-0.7 \% \\
\end{array}$ & $\begin{array}{r}310.5 \\
-3.0 \% \\
\end{array}$ \\
\hline \multicolumn{2}{|c|}{ 技術普及 } & 1995年以降一定 & $\begin{array}{l}\text { 市場メカニスム } \\
\text { により決定 }\end{array}$ & $\begin{array}{l}\text { 市場メカニスム } \\
\text { により決定 }\end{array}$ & $\begin{array}{l}\text { 市場メカニスム } \\
に \text { にり決定 }\end{array}$ & $\begin{array}{l}\text { 市場メカニスム } \\
\text { により決定 }\end{array}$ & $\begin{array}{l}\text { 市場メカニズム } \\
\text { により決定 }\end{array}$ & $\begin{array}{l}\text { 市場メカニズム } \\
\text { により決定 }\end{array}$ \\
\hline \multicolumn{2}{|c|}{ エネルギー転換部門対策 } & 考虑せず & 考虑せず & $\begin{array}{l}\text { एパウリング・ } \\
\text { 複合化等 }\end{array}$ & 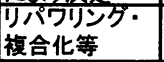 & $\begin{array}{l}\text { リパワリング・ } \\
\text { 複合化等 }\end{array}$ & $\begin{array}{l}\text { 勿複合化等 } \\
\end{array}$ & $\begin{array}{l}\text { リパワンク・ } \\
\text { 複合化等 }\end{array}$ \\
\hline \multicolumn{2}{|c|}{ 投資回収年 } & - & 3年 & 3年 & 3年 & 3年 & 3年 & 3年 \\
\hline
\end{tabular}

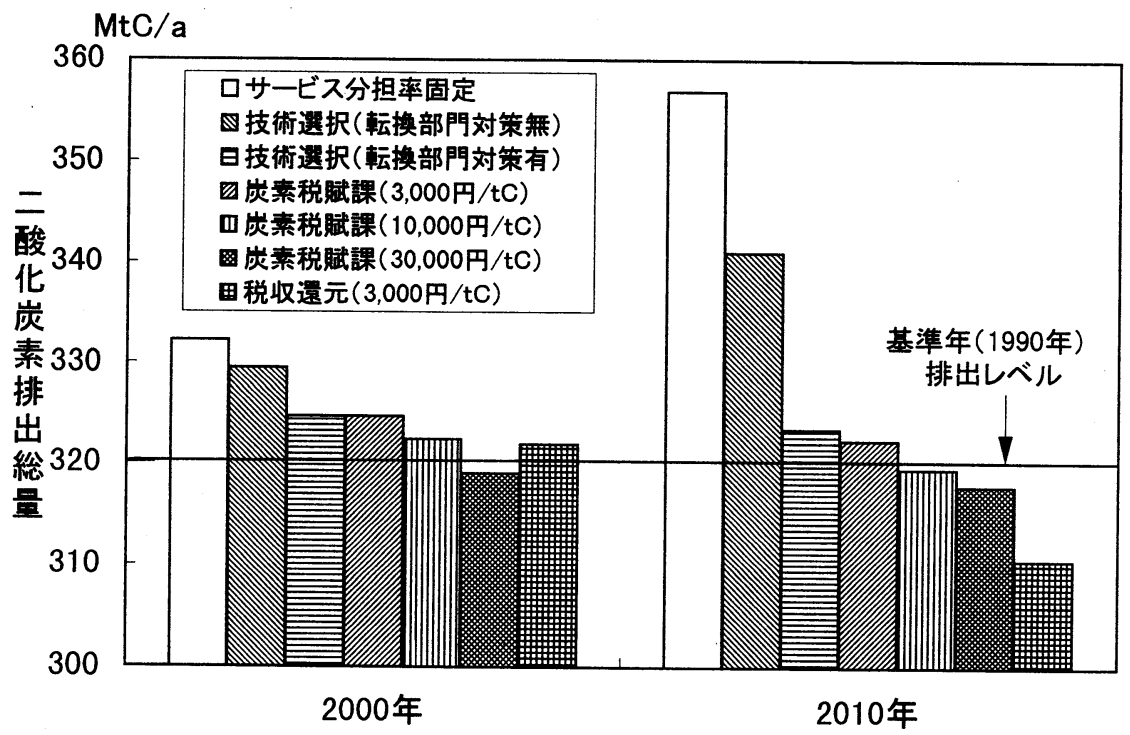

図 12000 年及び 2010 年の二酸化炭素排出総量推計值 
シミュレーション結果から次のことが導かれた。

1) サービス分担率固定ケースでは, 2000 年, 2010年における二酸化炭素排出量はそれぞれ, $332 \mathrm{MtC} / \mathrm{a}, 357 \mathrm{MtC} / \mathrm{a}$ で, 2010 年排出量は 1990 年に比べ約 $10 \%$ の伸びを示した。特に，需要サービスが将来的に高く見込まれる家庭， 業務で排出量が増加した。

2) エネルギー転換部門対策を考慮しない技術選択ケースでは，2000年までの各年の排出総量は分担率固定ケース と変わらなかった。しかし，2010年排出量は $341 \mathrm{MtC} / \mathrm{a}$ となり，1990年に比べ $6 \%$ の伸びに低減した。このケー スでは, 家庭部門において省エネ型ヒートポンプエアコンおよびインバータ蛍光灯が，業務部門においてガス 暖房が，運輸部門において直噴エンジン搭載車が主に普及した。産業部門のうち鉄鋼業では，溶融還元炉や電 気炉が高炉製鉄に代わって普及し，排出量を減らす要因となった。しかし，他の産業部門では，市場メカニズ ムによって買電から自家発電への移行が進み, 排出原単位の高い重油及び石炭の使用が増えた。しかし, 産業 部門全体の需要サービス量が減少したため，2010年の排出量は 1990 年に比べ約 $1 \%$ 減少した。

3) 技術選択ケースにてエネルギー転換部門対策を行う場合，炭素税の賦課あるいは補助金の導入がなければ 2000 年あるいは. 2010 年排出総量を 1990 年レベルの排出量に抑制するのは不可能であることが示された。

4) 炭素トンあたり 3 千円の炭素税を賦課した場合, 家庭及び運輸以外の分野では, 技術選択ケース（エネルギー 転換部門対策有）と比較した時の排出抑制効果はほとんどあらわれなかった。排出総量について，2010年排出 総量を 1990 年の排出レベルまで抑制させるには，炭素トンあたり 1 万円程度の課税が必要であった。

5) 炭素トンあたり 3 千円の炭素税賦課と補助金政策を組み合わせれば，炭素トンあたり 3 万円の課税よりも排出 抑制効果があり，2010年排出量を 1990 年レベル以下に抑制することが可能となった。

6) 本計算では, 買電は自家発電に比へ経済性が低くなる。したがって産業部門は電力源として自家発電を優先し た。しかし, 買電電力の二酸化炭素排出量原単位は, 発電の原子力化及びリパワリング, 複合化サイクル発電 の普及などによって低くなる。したがって，補助金を導入したケースでは，買電は市場での競争力を回復した。

\section{5 おわりに}

この論文では，現在，著者らが開発・使用しているエンドユーズタイプの二酸化炭素排出量推計モテルと，それを 使用して推計したわが国の二酸化炭素排出量見通しについて報告した。このモテルは，1992年から開発が始められ， 随時, アルゴリズム及びデータインターフェースなどに改良が加えられてきた（AIM/Japan 開発チーム, 1994、AIM Project Team，1996）。その間，技術・経済テータの収集・蓄積を図ってきたが，現在ではその更新も作業の大部分 を占めている。また, 開発当初は, 計算基準年を 1985 年としていたが, 今回の計算では 1990 年を基準年としており, 基準年変更によるキャリブレーション等にも多大な労力を必要とした。推計アルゴリズムに関しては, 当初は, サー ビス種別の最適化計算を積み上げるアカウンティングモテル的なものであったが，次いでサービス種・部門をまたが る最適化, さらには政府・機器購入者間のシュタッケルベルグ行動的な補助金交付アルゴリズムを取り込むに至って いる。このように，本モテルは，技術最適化モデとしては，開発初期のフィージビリティスタティ段階を脱し，オ ペレーショナル段階に入ってきたと考えてよかろう。

当初, 二酸化炭素排出量推計を行うモテルの開発を開始するにあたって, 著者らはその目標像を次のように想定し ていた。

1) 各技術・機器がもつ工学的, 経済的な諸元・特徴が, 二酸化炭素排出量にどのように結びついているかをモテ ル中に明示的に記述し，それに基づいた解析を行うことによって，二酸化炭素排出抑制手法の具体的評価を行 うことを可能とする。この性格は，エネルギー価格付け・補助金交付に強い戦略性を必要とする開発途上国に て要求度が高いと考えた。

2) 技術選択を近視眼的ではなく長期的最適に行ったり，機器・技術の価格付けの学習効果とその期待を明示的に 取り込むアルゴリズムを準備する。これらのメカニズムとエネルギー技術・機器整備資金に関する諸制約を複 合して算出される諸推計は, 1) と同様に開発途上国にて有用度が高いであろう。 
3) エネルギーサービス需要の発生構造を記述するモジュールを構筑し, 社会・経済の諸環境因子, ライフスタイ ルや環境保全意識の変化を明示的に反映するメカニズムを組み込む。

4) トップダウン型モデル及び産業連関構造と組み合わせ, エネルギー価格変化のマクロ経済的影響を取り込んだ エネルギーマクロ経済リンケージや部門間のエネルギー投入・産出連関を分析するエネルギー連関リンケージ (Munasinghe and Meier, 1993) などを考虑する。

これらのうち，1)に関しては, 本論文で取り扱ったモデルでほぼ対応し得たと考えている。2)に関しては, 数理計 画法上いくつかの困難な点を含むほか，モデパラメー夕の取得にも多くの解決すべき点があるが, 最近, これらの メカニズムを取り込もうとする試みもなされており，それらを参考にして検討中である。3)に関しては，1)，2) とは 異なったより基本的な問題点を包含している。ロジスティック曲線によるサービス需要の外挿はしばしば多用される 方法であるが，これでは施策に対する現実性と操作性を大きく損なってしまう。また，これらを明示するのに規範的 な観点をどの程度取り入れるかも大きな争点となろう。4)に関しては, 計算労力さえ厥わなければ, 致命的な問題点 はないと考えられ, 現在, J.Edmonds らが開発しているSGM (Second Generation Model, Edmonds, 1995) との 結合に関する共同作業を進行中である。以上のように, 本モテルに関し今後解決・発展すべき点は大変多く, 今後も, これらについて随時, 改良・改訂する努力を続けていく予定である。

\section{謝辞}

本研究は, 著者らと国立環境研究所甲斐沼美紀子主任研究員, 韓国環境技術開発院李東根研究委員, 富士総合研究 所吉田雅也氏による共同研究である。また, その遂行にあたっては, 環境庁地球環境研究総合推進費の援助を受けた。 これらを記して感謝の意を表す。

\section{引用文献}

AIM/Japan 開発チーム, 1994, 技術選択を考慮したわが国の二酸化炭素排出量の予測モテルの開発, F-64-'94/NIES, 国立環境研究所.

AIM/Japan Project Team, 1996, A guide to the AIM/ENDUSE model - Technical selection program with linear programming -AIM Interim Paper, IP-95-05.

B.Chateau and B.Lapillonne, 1979, Long Term Energy Demand Simulation, (in) Energy Models for the European Community, An Energy Policy Special, Guildford.

Finon,D., 1974, Optimization Model for the French Energy Sector, Energy Policy, 2.

Fishbone,L.G. and H.Abilock, 1981, MARKAL, a linear-programming model for energy systems analysis, technical description of the BNL version, Energy Research, 5.

J.Edmonds, 1995, Modelling future greenhouse gas emission: The second generation model description, (in) Modelling global change, (eds.) Klein,L.R. and Lo,F., United Nations University Press.

環境庁地球環境部編, 1994, 温暖化する地球・日本の取り組み, 大藏省印刷局.

M.Munasinghe and P.Meier, 1993, Energy policy analysis and modeling, Cambridge.

SEI-B(Stockholm Environment Institute - Boston), 1993, The Long-range Energy Alternatives Planning System, Overview for LEAP version 94.0.

資源エネルギー庁，1996，1995/1996 年版 資源エネルギー年鑑，通産資料調查会.

志水清孝, 1982, 多目的と競争の理論, 共立出版.

通産省産業政策局, 1994，21 世紀の産業構造，通商産業調查会.

Varian,H.R., 1984, Microeconomic analysis, Norton \& Company. 